\title{
Erratum to: Knowledge and epistemic necessity
}

\section{John Hawthorne}

\section{Erratum to: Philos Stud (2012) 158:493-501 \\ DOI 10.1007/s11098-012-9960-1}

To the reader of this issue: Due to an oversight, Professors Dougherty and Rysiew's paper was omitted from the final reference list in this article. Please note that where Dougherty \& Rysview's paper is mentioned in the text this refers to:

Dougherty, Trent, and Patrick Rysiew. "Fallibilism, Epistemic Possibility, and Concessive Knowledge Attributions," Philosophy and Phenomenological Research, 78:1, 123-132, January 2009."

The online version of the original article can be found under doi:10.1007/s11098-012-9960-1.

\section{J. Hawthorne $(\bowtie)$}

Magdalen College, University of Oxford, Oxford OX14AU, UK

e-mail: john.hawthorne@philosophy.ox.ac.uk 